\title{
Author Correction: Interrogation of $\gamma$-tubulin alleles using high- resolution fitness measurements reveals a distinct cytoplasmic function in spindle alignment
}

Kristian Shulist, Eric Yen, Susanne Kaitna, Allen Leary, Alexandra Decterov, Debarun Gupta \& Jackie Vogel

Correction to: Scientific Reports https://doi.org/10.1038/s41598-017-11789-7, published online 12 September 2017

The Acknowledgements section in this Article is incomplete.

"The authors thank current and past members of the Vogel lab for stimulating discussions during this work, Brian Leung (McGill Biology) for input during the development of GAMER, and Elke Küster-Schöck and Guillaume Lesage for robotics support."

should read:

"The authors thank current and past members of the Vogel lab for stimulating discussions during this work, Brian Leung (McGill Biology) for input during the development of GAMER, and Elke Küster-Schöck and Guillaume Lesage for robotics support. The research was supported by a fellowship from the Natural Sciences and Engineering Research Council awarded to KS and operating grants from the Natural Sciences and Engineering Research Council (262246), the Canadian Institutes of Health Research (123335) and the Fonds Nature et technologies (191128) awarded to JV."

(c) (i) Open Access This article is licensed under a Creative Commons Attribution 4.0 International License, which permits use, sharing, adaptation, distribution and reproduction in any medium or format, as long as you give appropriate credit to the original author(s) and the source, provide a link to the Creative Commons license, and indicate if changes were made. The images or other third party material in this article are included in the article's Creative Commons license, unless indicated otherwise in a credit line to the material. If material is not included in the article's Creative Commons license and your intended use is not permitted by statutory regulation or exceeds the permitted use, you will need to obtain permission directly from the copyright holder. To view a copy of this license, visit http://creativecommons.org/licenses/by/4.0/.

(C) The Author(s) 2018

Department of Biology, McGill University, 3649 Promenade Sir William Osler, Montreal, Quebec, H3G 0B1, Canada. Kristian Shulist and Eric Yen contributed equally to this work. Correspondence and requests for materials should be addressed to J.V. (email: jackie.vogel@mcgill.ca) 